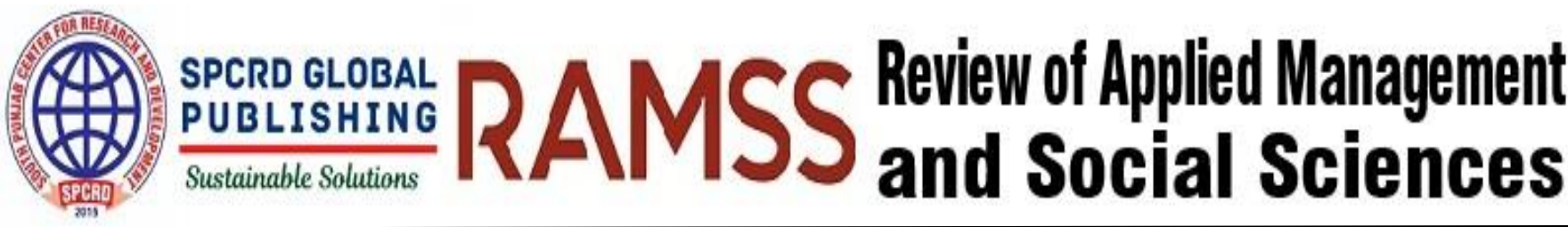

\section{Classroom Management Techniques: A Framework to Practice}

\author{
${ }^{a}$ Muhammad Latif Javed, ${ }^{b}$ Muhammad Asif Choudhary, ${ }^{c}$ Rashid Ahmad \\ a Lecturer, Department of Education, The Islamia University of Bahawalpur, Bwn Campus, Pakistan: Latif.javed@iub.edu.pk \\ b SST, Govt High School, Mirpur (AJK): asif_10200@yahoo.com \\ c Assistant Professor, School of Economics Bahaudin Zakariya University Multan, Pakistan: rashidahmad@bzu.edu.pk
}

Corresponding author's email address: Latif.javed@iub.edu.pk

\begin{tabular}{l}
\hline ARTICLE DETAILS \\
\hline History: \\
Accepted 29 December 2019 \\
Available online 31 December 2019
\end{tabular}

Keywords:

Classroom Management, Management Techniques, Management Framework, Elementary Level

\section{JEL Classification:} A23, M54, C61

DOI: $10.47067 /$ ramss.v2i2.17
An effective classroom management is the key to better teachinglearning results and outcomes. It relates to creating a learning environment and focuses on developing an appropriate students' behavior at early stage of students' life. The main objective of the study was to analyze the classroom management techniques within the framework, used by elementary school teachers to make the process operative and successful at school level. The framework developed through the elements three main aspects static, dynamic and teachers' perception about classroom management practices All the teachers teaching at elementary level and students enrolled at elementary level in district Mirpur (A.K) comprised the population. Data obtained was analyzed; the frequency, percentage and ranking were calculated. It revealed that the environment of classroom was generally suitable for teaching-learning process. It was recommended to provide teaching A.V Aids to teachers accordingly their classrooms need. Teachers should modify their management techniques to meet the students' needs on basis of individual differences of students' in classrooms. As authoritative attitude of teachers discourages the student in their learning, there was need for a friendly environment so that teachers and students can work together to produce good results.

(C) 2019 The authors. Published by SPCRD Global Publishing. This is an open access article under the Creative Commons Attribution-

NonCommercial 4.0

\section{Introduction}

The impact Education is a lifelong process of human being. This process is formally starting when a child gets admission in a school. According to Guinness Encyclopedia, (p.624, 1987) "Education is a process that allows each new generation to learn and sometimes challenge the knowledge, skills and values that has been established by previous generation". 
Classroom management is important to everyone connected with education. It directly relates to the discipline and behavior of the students, and how they utilize their time in classroom. It also relates to teachers' control of their classes. Experienced usually cite establishing management as a major goal in the first few weeks of the school years. The amount of control that teacher have in the class is often seen by the administration as a measurement of the quality of a teacher. School principals and administrators give low rating to teachers who lack control of their classes. Thus, proper management of classes becomes a prerequisite for good education. According to Emmer, Everston, Clements and Worsham (1997, p.111);

Good management of classroom depends on the process of planning, coordination/cooperation, motivation, feedback and evaluation of classroom organization, instructions, rules and procedures. All preparations will pay large dividends once the students arrive. However, being ready is not sufficient to sustain good behavior throughout the year. You will need to be dynamically involved in maintaining student assistance and compliance with necessary classroom procedures and rules.

The effective classroom management means the use of different techniques that increase student active involvement in different classroom activities and thus avoid occurring problems in management of classroom. There is a strong affiliation between teacher and student behavior. By utilizing maximum time that students spend in educational activities can result to minimize the discipline problems. It can also enhance by resolving incidents of unimportant inattention before they extend into main disruptions.

A quality of the schools is distinct by teacher efficiency and student achievement under the support of building strong interpersonal skills. In this connection, relationships of teacher and student are necessary to ensuring a positive classroom environment. The discipline problems of classroom management can be deal with either individually between teacher and student or by group class meetings. As mutual trust develops between teacher and students', the later are slowly released from teacher control by becoming individual responsibility. It is how both "educators and students become co-participants in the teaching-learning process, striving to make the most of themselves and their collective experience" (Froyen \& Iverson, 1999, p. 256).

Poor classroom management and class control, student discipline and disturbing student behavior are some general complaints concerning school made by students, parents, teachers and administrators. Majority teachers agree that classroom teaching is greatly impacted by management of classroom. It is important to creating a close relation of trust, value and interest with students. Lieberman and Miller (1999, p.7) say: it required sustainable support from the leadership by facilitating time, focusing resources and protection from additional responsibilities.

The classroom learning environment develops gradually. It is influenced by teachers' communication of expectations, modeling of behavior, and approach to classroom management. The same class that is interested and attentive with one teacher can be bored and restless with another. It strongly indicates that certain teacher attitudes are required for effective classroom management. The attitudes and principles of classroom management complement from one another to form a systematic approach. Research on classroom management has yielded a knowledge base that offers a coherent set of principles to guide teachers in making decisions about how to manage their classrooms. According to Good and Brophy (1997, p.127) the findings converge on the conclusion that teachers who approach classroom management as a process of establishing and maintaining effective learning environments 
need to be more successful than teachers who place more emphasis on their roles as authority figures or disciplinarians.

Attempts to manage a classroom with the help of isolated techniques are not successful. Students should involve in focus activities throughout a class period. They need to keep motivated through a simple and clear method of teaching.

\section{Statement Of The Problem}

Classroom management is an essential part of teaching learning process. Keeping in view its importance the present research is aimed to study on the "Classroom Management Techniques used within the framework by Elementary School Teachers in District Mirpur (A.K)”.

\section{Objectives of The Study}

The study based on the following major objectives:

1) To study the classroom management techniques being applied under the prevailing framework at elementary level.

2) To identify the problems of elementary teachers applying classroom management techniques

\section{Significance of The Study}

This study was aimed to develop classroom management techniques which are useful in the wider perspective of the objectives and aims of education. It also reflects on what teacher believes; and describes assumptions they made about the nature of teaching, learning and classroom management. It designed to influence the types of lessons they plan and teach. It also supports in reducing discipline problems and give guide line to deal with such problems effectively and efficiently whenever they occur. The study also important as it deals with the problems of misbehaves and carelessness at all level of classroom. The study provides a approach into different teaching motivational techniques like praise and reinforcement. It helps the teacher in creating a learning environment and give direction about inconsistency resolution in the classroom.

\section{Research Questions}

i) What are the management techniques being used by the elementary school teachers in their classroom?

ii) How these management techniques, are in classroom management?

iii) How these techniques can be improved?

\section{Review Of Literature}

Educationists are anxious with the questions; how do teachers learn to behave in the way they do their work in classroom? How teacher and students affect each other's behavior? How students behave in classroom? By answer these questions teachers can have a positive influence on the interests, learning, and progress of students. Teachers usually manage the physical, spatial and time provision in schools that is an important part of their duty. Schools and classrooms are areas of interaction, providing a learning environment for both teacher and students. All teachers and educationists recognize classroom management as one of the most important aspect of instruction.

Generally Teachers do not want to give control to their students. A class control is considered the mark of a good teacher. The quality of the teacher is often measured by administration by seeing teacher class control. Administrators consider efficiency of the teacher and are usually happy if a teacher in no 
way sends a student to the office. This means as proof that the teacher managed and control classroom well and doing a good job. (Edwards, 1994)

The management of classroom refers to the concern and maintenance of an atmosphere in which teaching and learning process can take place efficiently. The objective of the classroom management is to develop and increase student learning. Averting of misbehavior, tidy environment and discipline are all related issues to classroom management. It, therefore, means to make a encouraging environment where students can learn and grow up as precious persons.

Good management of classroom can help teachers to deal with the complicated demands of teaching a great number of students for number of periods per day. It saves student and teacher time for learning. Inappropriate management interferes with learning and teaching, which causes disturbance waste of time in other ways. In fact, good classroom management is necessary for a healthy learning environment.

Teachers have to deal with individuals differences of students and as social beings. It is clear that students learn more than subject matter in schools. They have to teach a class or group much of the time and try to respond to the needs of individual students. In classrooms good achievement is possible that function in an encouraging atmosphere; under the teachers' guidance. Classroom management can be very helpful for teaching learning process in schools. A Classroom play the key role to the process lies in developing students feel proficient and associated. It is therefore very important that teachers develop their knowledge about different kind and components of the classroom.

\section{Components of Classroom}

Classrooms have many purposes as teachers make schedules, keep records, monitor students' activities, accumulate and evaluate student class work. In the same way different things happen in the classroom, that teachers listen during discussion, also teacher helps students' in their difficulties in classroom answer and monitor students for symbols of learning aspect. Many classroom actions performed and occur in very high speed due to this situation teachers have to tackle it. Every day these actions change their situation and some of them very difficult to forecast. After few weeks or months common norms and perceptive develop among students. These develop the students' behaviors for the future learning. Classroom has different elements. These may these components can be students, teachers, teaching A.V aids and different type of materials.

There are some more components that are classroom rules and school values, timetable, curricula, plans and policies, roles and tasks. Joyce, Weil and Showers (1992, p.1) say, "Classroom is the social system for the students of learning and growing for the future."

In schools and classrooms play different role such as any organization. These components have differently take part in this organization. Teachers should know much information to manage their classrooms efficiently and effectively. Teachers mostly concern with different components of classrooms. These different components of a classroom that are students, teachers, and teaching techniques are the parts of classroom management techniques.

\section{Students}

It is very important that student positive behavior and concern in the classroom help learn. Students' have their individual differences and have different level of learning in classroom. Therefore special need for different learning approaches for effective learning and teaching process for these students. Students also have their own ability to learn and how they have contact and deals with different 
problems. It depend upon them how they can learn.

There are five different types of students byGood and Brophy (1997, pp. 333. 334). These are as follows:

Social students, Successful students, Dependent students, Phantom students, Alienated students.

\subsection{Social Students}

This type of student express those worker other activities with their friends in socially. These have less time for their work on class room assignments.

\subsection{Successful Students}

In this type of students, students are hard worker in their activities and very successful in study. These Students have positive attitude in their all school and classroom activities, but have some problems.

\subsection{Dependent Students}

Mostly this type of the students looks to help and guidance from other the teacher for support and commonly asks for direction and help. Teachers help them for students' improvement in academic difficulties.

\subsection{Phantom Students}

These type of students hardly ever Participate actively in group activities and remain in the background. Majority of these are shy, uneasy students and others are quite. These types of students are independent workers of normal ability. Mostly teachers like to forget phantom students.

\subsection{Alienated Students}

These students are probable dropouts' extremely unwilling learners and these students create problems and reject school and hostile.

\subsection{Teacher}

All over the world teachers are often required to obtain specialized education, knowledge, codes of ethics and internal monitoring. There are a variety of bodies designed to instill, preserve and update the knowledge and professional standing of teachers. Teachers place at the crossing position of the transmission of knowledge, values and skills. All over the world many governments operate teacher's colleges, which are generally established to serve and protect the public interest through certifying, governing and enforcing the standards of practice for the teaching profession. Teacher is to be considering the symbol of development of nation. It requires competence and command on subject matter and contents. Teachers need to focus on different aspect of classroom concerning that are students discipline, class control, subject matter, and communication in the classroom. Teachers also have deeply looked on activities organized and performed by students and then monitor these activities.

\subsection{Teaching}

This component of the classroom is very important which play active role in classroom for learning process for students. There are essential requirements for the effective learning and teaching process. Teaching is vital role which need favorable conditions for it activeness.

According to Nacino. Oke and Brown (1982, p.2), "Teaching is a process that someone attain to perform for change the behavior of others and acquire knowledge and different skills. The effective teaching has always a positive effect on other attitudes which help to learn in classroom. Through it students work and take active part in their learning process. Quina (1989 .p.8).says "Effective and 
efficient teaching required relationship between the students' and teachers' attitude.”

Teaching involve creative work that process through different teaching skills, teachers responsibilities and contents of subject. These are the basic areas for a competent and professional teacher. Panda (1997). Teachers should also require teaching A.V aids audio-visual equipment for efficient teaching that result better learning. There is some very important information about any classroom which teacher requires having knowledge about it.

\section{The Classroom Environment}

Effective teaching learning process needs such positive environment where the aim and objective of education can achieve by smooth running of educational activities accordingly. It is quality of a good teacher who establishes conducive environment where students' learning process occurs according to the students' needs and interests.

Mayeski (2005. P.1) says "The place where student gather to learn is a classroom. A systematic atmosphere in the classroom is for better teaching and learning process.”

There are three basic components the classroom physical components, social components and educational components. The teacher can arrange and manage each. These components will then provide for better management for classroom.

\subsection{Physical Component of the Classroom}

It consists of size of the classroom room, structure of classroom, type of furniture, seating arrangement of students, blackboard, audiovisual equipment's, and other teaching learning materials. Classroom has its own variety of equipment, and different type of materials. The students can share while others are for use of individual. There are various other things that are limited to use only by the teacher.

Classrooms should be fully clean and nicely decorated with student creations, however free from disturbing stimuli. The seating arrangement of students' should allow students to work considerately as well as allowing the teacher to move freely and efficiently.

A number of different factors make the physical components of the classroom. So it is important, teachers need to consider each of these component in order to appropriately manage their classroom. These factors are very helpful for classroom management. These are Visual, Thermal, Noise (Acoustic), Spatial, and time factor.

\subsection{Social Component of the Classroom}

This component of classroom environment consists of students and teacher within a classroom or any other educational situation. Every classroom is different from any other classroom setting. In this respect a teacher has to work with different kinds of students, with individuals within the larger group, with different groups both small and large. The social organization of classrooms varies extremely from school to school and it considerably affects teachers' commitment, cooperation, leadership, and the quality of both students' and teachers' school lives.

\subsection{Arrangement of Classroom}

In management of students' activities and tasks during a lesson good classroom arrangement helps teachers positively. Classroom arrangement proved a helpful and effective role in teaching learning process. 
Nature of learning activities based on classroom arrangement in educational environment. There are different aspects of room arrangement. Some of these are students' use of materials, students' interaction with the teacher, students' interaction with each other, and situation of movement in the classroom. A teacher can learned choices and adapt arrangements to suit particular teaching learning conditions that room arrangement requires. According to John. (1993, p. 63) the different arrangements of seating are; cluster shape, rows and columns shape, and Circles shape with teacher and students desire to set anywhere in the school to make a classroom.

\section{Freamework to Practice}

Framework to practice classroom management mainly surrounded by important elements, which can be divided into two categories; one is static and the other one is dynamic. The static can be: The outline of lessons, curricular or co-curricular activities, classroom organization, equipment, audio-visual aids and other materials influence the students' academic attainment and their attitude in relation to their teacher, educational activities and peers group. These also have various implications for future learning of students. There are also different elements of classroom environment that influence behavior, impressions and attitudes. The environment or atmosphere provides the situation in which behavior takes place. It provides the consequences that follow behavior.

The environment requires to be changed if students' growth is to continue at maximum rate because as the individual student becomes more complex. It is not adequate to provide presentations, interesting activities and clear instructions. Students do not learn only by hearing or by watching about the best way to do things. They learn by doing and also by experience the consequences of their actions.

In the same way the second element can be: The actions that follow a behavior are very important in determining if the behavior will be ignored, strengthened, maintained, or discarded. Pleasant or attractive consequences increase the chances that the behavior will occur again. These provide to shape the sample of behavior over a period of time and in different settings by strengthening some behavior and weakening others behavior.

\section{Classroom Management}

Management is the process of integrating all resources and tasks towards the achievement of stated goals. It is a systematic and organized way of doing things. It deals with resources, tasks, goals, and the operation of an organization. A manager's objective is to achieve organizational goals and is concerned with efficiency and effectiveness.

According to Robbins and Coultar (1996, p.8), “The term management refers to the process of getting activities completed efficiently and effectively with and through other people”.

Classroom management is defined as the methods and strategies an educator uses to maintain a classroom environment that is conducive to student success and learning. Although there are many pedagogical strategies involved in managing a classroom, a common denominator is making sure that students feel they are in an environment that allows them to achieve.

In a classroom it is a practical activity as it relates to making the classroom work. It is related to the school aims, the construction of a model of education for the students, and the shaping of a set of moral and behavioral norms for them. It requires ability that is conceptual, judgmental, and ethical. 
According to teaching tips (2005, p. 1), "Classroom Management refers to the procedures and routines that are used to keep the daily business of the classroom running smoothly".

Solis (2005, p. 1) says, "Ideally classroom management should be a common understanding between the teacher and the students. There are three major components on which classroom management focuses:

i) Content management

ii) Conduct management

iii) Covenant management

\section{Methodology of the Study}

The study was descriptive in its nature and survey method was used. It involved the collection, analysis and interpretation of data for the purpose.

\subsection{Population}

126 teachers teaching at elementary schools for boys in class 6th to 8th in district Mirpur comprised the population.

\subsection{Sample}

The District Mirpur has 2 tehsils, Dadyal and Mirpur. The Sample of study consisted of both tehsils of District schools. $100 \%$ (i.e. 126) Teachers teaching for class 6th to class 8th in Elementary (boys) Schools.

Table: $1 \quad$ Population and Sampling Framework NR=126

\begin{tabular}{lllllll}
\hline & & \multicolumn{3}{l}{ Population } & \multicolumn{3}{l}{ Sample } & \\
\cline { 5 - 7 } No. & Tehsil. & Schools & Teachers & Schools & Teachers & \%age \\
\cline { 1 - 4 } \cline { 5 - 7 } 1 & Mirpur & 26 & 78 & 26 & 78 & $100 \%$ \\
2 & Dadyal & 17 & 48 & 17 & 48 & $100 \%$ \\
\hline
\end{tabular}

\subsection{Tool for Research Instrument}

The questionnaire was prepared in consultation with the supervisor and the expert in the field of educational research and was improved in the light of their suggestions. The refined questionnaire was used for data collection.

\subsection{Collection of Data}

Data was collected through questionnaire, and personally delivered to the respondents. The respondents were a briefed about the nature of the study. Efforts were made to collect data by involving the district education management of Mirpur.

\subsection{Analysis of Data}

The collected data were entered in computer. It was tabulated analyzed and interpreted by using SPSS, Version- 21 to find the analysis to reach the findings.

Statistical analysis of the problem and presentation of data through the tables are the main features of this section of the study. For the analysis of data percentage of the responses were calculated by converting SA \& A to SA and SD \& D into SD. As the practiced framework mainly consisted of two elements these were static, dynamic and teachers' perception about problems with respect to their effect 
on classroom management. Data was collected using a five point likert scale questionnaire. The questionnaire for teachers consisted of 26 statements having aspects of framework on classroom management for the response of each item.

The two types of these elements are:

- Static: Classroom size, Furniture, Environment, students, teacher and availability of A, V- aids.

- Dynamic: Students' behavior \& attitude, teacher behavior and attitude, atmosphere of the classroom, teaching methods and personality traits of the teacher.

Teachers' Perception: Classroom size \& no of students, Availability of A.V aids and Teacher student ratio

1. SUMMARY, FINDINGS, AND RECOMMENDATIONS

Table: 1 Data Analysis (Aspects of Classroom Management \& Teachers' Perception)

\begin{tabular}{|c|c|c|c|c|c|c|c|c|c|}
\hline \multirow{3}{*}{$\begin{array}{l}n \\
z \\
z\end{array}$} & \multirow{3}{*}{ 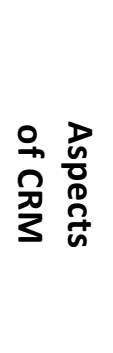 } & \multirow{3}{*}{ 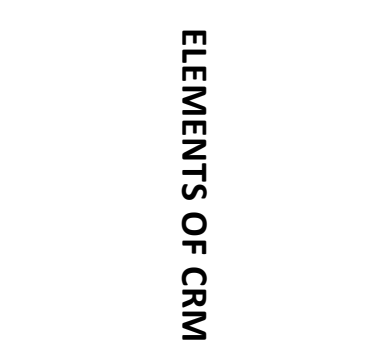 } & \multicolumn{7}{|c|}{ Responses } \\
\hline & & & \multirow{2}{*}{ 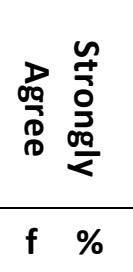 } & $\underset{\substack{D \\
\frac{0}{D}}}{D}$ & $\begin{array}{l}\frac{c}{3} \\
\hat{D} \\
\frac{0}{7} \\
\frac{D}{5} .\end{array}$ & 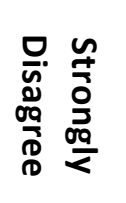 & 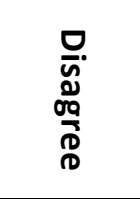 & \multirow[t]{2}{*}{ 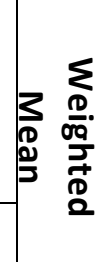 } & \multirow[t]{2}{*}{$\ddot{\sigma}$} \\
\hline & & & & f $\%$ & f $\%$ & f $\%$ & f $\%$ & & \\
\hline \multirow{6}{*}{1} & \multirow{6}{*}{$\begin{array}{l}n \\
\stackrel{n}{n} \\
\frac{n}{n}\end{array}$} & $\begin{array}{l}\text { a) Classroom } \\
\text { size }\end{array}$ & $\begin{array}{c}51 \\
(40.0 \%)\end{array}$ & $\begin{array}{c}55 \\
(44.7 \%)\end{array}$ & $\begin{array}{c}12 \\
(9.4 \%)\end{array}$ & $\begin{array}{c}8 \\
(5.9 \%)\end{array}$ & $\begin{array}{c}0 \\
(0.0 \%)\end{array}$ & \multirow{6}{*}{4.1} & \multirow{6}{*}{0.55} \\
\hline & & b) Furniture & $\begin{array}{c}65 \\
(51.7 \%)\end{array}$ & $\begin{array}{c}61 \\
(48.23 \%)\end{array}$ & $\begin{array}{c}0 \\
(0.0 \%)\end{array}$ & $\begin{array}{c}0 \\
(0 \%)\end{array}$ & $\begin{array}{c}0 \\
(0.0 \%)\end{array}$ & & \\
\hline & & c) Environment & $\begin{array}{c}57 \\
(45.9 \%)\end{array}$ & $\begin{array}{c}55 \\
(44.7 \%)\end{array}$ & $\begin{array}{c}8 \\
(5.9 \%)\end{array}$ & $\begin{array}{c}3 \\
(2.4 \%)\end{array}$ & $\begin{array}{c}3 \\
(1.2 \%)\end{array}$ & & \\
\hline & & d) No of Student & $\begin{array}{c}30 \\
(24.7 \%)\end{array}$ & $\begin{array}{c}55 \\
(44.7 \%)\end{array}$ & $\begin{array}{c}22 \\
(18.8 \%)\end{array}$ & $\begin{array}{c}14 \\
(11.8 \%)\end{array}$ & $\begin{array}{c}0 \\
(0.0 \%)\end{array}$ & & \\
\hline & & $\begin{array}{ll}\text { e) } & \text { No of } \\
\text { Teachers }\end{array}$ & $\begin{array}{c}50 \\
(40.0 \%) \\
\end{array}$ & $\begin{array}{c}55 \\
(44.7 \%) \\
\end{array}$ & $\begin{array}{c}12 \\
(9.4 \%) \\
\end{array}$ & $\begin{array}{c}3 \\
(1.2 \%) \\
\end{array}$ & $\begin{array}{c}8 \\
(5.9 \%) \\
\end{array}$ & & \\
\hline & & f) A.V aids & $\begin{array}{c}9 \\
(23.5 \%)\end{array}$ & $\begin{array}{c}56 \\
(45.9 \%)\end{array}$ & $\begin{array}{c}18 \\
(14.1 \%)\end{array}$ & $\begin{array}{c}15 \\
(12.9 \%)\end{array}$ & $\begin{array}{c}4 \\
(3.5 \%)\end{array}$ & & \\
\hline \multirow{5}{*}{2} & \multirow{5}{*}{ 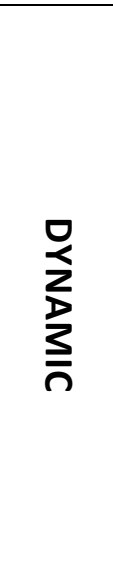 } & $\begin{array}{l}\text { a) Students' } \\
\text { Behavior }\end{array}$ & $\begin{array}{c}18 \\
(36.5 \%)\end{array}$ & $\begin{array}{c}20 \\
(38.8 \%)\end{array}$ & $\begin{array}{c}16 \\
(12.9 \%)\end{array}$ & $\begin{array}{c}18 \\
(36.5 \%)\end{array}$ & $\begin{array}{c}19 \\
(38.8 \%)\end{array}$ & \multirow{5}{*}{3.8} & \multirow{5}{*}{0.41} \\
\hline & & $\begin{array}{l}\text { b) Teachers' } \\
\text { Behavior }\end{array}$ & $\begin{array}{c}62 \\
(50.6 \%)\end{array}$ & $\begin{array}{c}52 \\
(42.4 \%)\end{array}$ & $\begin{array}{c}6 \\
(4.7 \%)\end{array}$ & $\begin{array}{c}3 \\
(1.2 \%)\end{array}$ & $\begin{array}{c}3 \\
(1.2 \%)\end{array}$ & & \\
\hline & & $\begin{array}{ll}\text { c) } & \text { Teacher } \\
& \text { Students } \\
& \text { interaction } \\
\end{array}$ & $\begin{array}{c}18 \\
(36.5 \%)\end{array}$ & $\begin{array}{c}19 \\
(38.8 \%)\end{array}$ & $\begin{array}{c}15 \\
(12.9 \%)\end{array}$ & $\begin{array}{c}12 \\
(10.6 \%)\end{array}$ & $\begin{array}{c}3 \\
(1.2 \%)\end{array}$ & & \\
\hline & & $\begin{array}{ll}\text { d) Students } \\
\text { attitude }\end{array}$ & $\begin{array}{c}62 \\
(49.1 \%) \\
\end{array}$ & $\begin{array}{c}51 \\
(40 \%) \\
\end{array}$ & $\begin{array}{c}6 \\
(4.7 \%) \\
\end{array}$ & $\begin{array}{c}4 \\
(3.5 \%) \\
\end{array}$ & $\begin{array}{c}3 \\
(2.3 \%) \\
\end{array}$ & & \\
\hline & & $\begin{array}{l}\text { e) Teachers' } \\
\text { attitude }\end{array}$ & $\begin{array}{c}20 \\
(38.8 \%)\end{array}$ & $\begin{array}{c}64 \\
(51.8 \%)\end{array}$ & $\begin{array}{c}8 \\
(8.2 \%)\end{array}$ & $\begin{array}{c}3 \\
(1.2 \%)\end{array}$ & $\begin{array}{c}0 \\
(0.0 \%)\end{array}$ & & \\
\hline \multirow{2}{*}{3} & \multirow{2}{*}{ 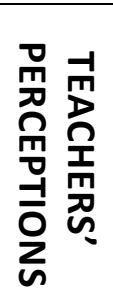 } & $\begin{array}{ll}\text { a) } & \text { No of } \\
\text { Students/Teac } \\
\text { hers }\end{array}$ & $\begin{array}{c}43 \\
(34.1 \%)\end{array}$ & $\begin{array}{c}32 \\
(27.1 \%)\end{array}$ & $\begin{array}{c}27 \\
(22.4 \%)\end{array}$ & $\begin{array}{c}15 \\
(12.9 \%)\end{array}$ & $\begin{array}{c}4 \\
(3.5 \%)\end{array}$ & \multirow{2}{*}{3.7} & \multirow{2}{*}{0.8} \\
\hline & & $\begin{array}{l}\text { b) No of } \\
\text { Teachers/class }\end{array}$ & $\begin{array}{c}50 \\
(40.0 \%)\end{array}$ & $\begin{array}{c}62 \\
(49.4 \%)\end{array}$ & $\begin{array}{c}21 \\
(17.6 \% \\
)\end{array}$ & $\begin{array}{c}3 \\
(1.2 \%)\end{array}$ & $\begin{array}{c}8 \\
(8.2 \%)\end{array}$ & & \\
\hline
\end{tabular}




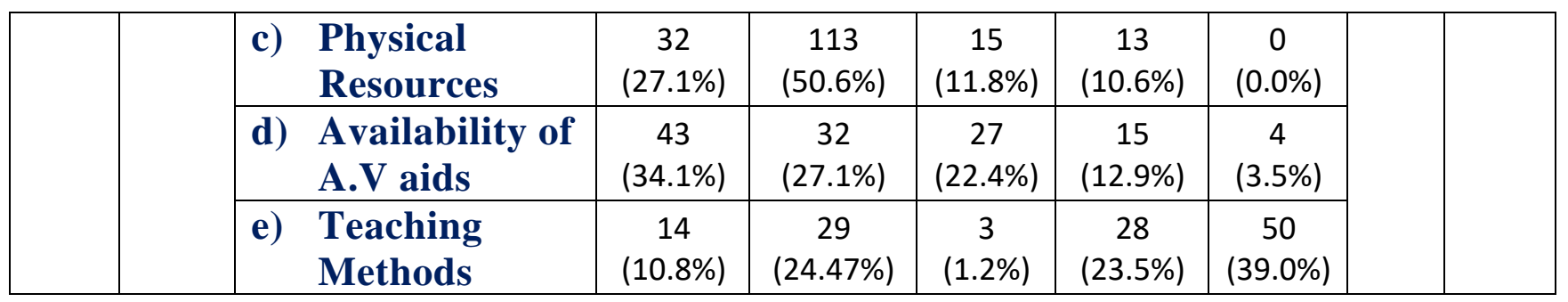

\section{Summary}

The study was conducted to classroom management techniques used by the Elementary schools Teachers in district Mirpur (A.K). The objectives of this research were to study the classroom management techniques being applied by teachers of elementary schools in district Mirpur and to identify the problem areas are being faced by teachers and to suggest measures for further improvements. The research was aimed to analyzing the role played by the teachers for effective teaching and learning process by use of classroom management techniques.

The target population for the study comprised of Govt. Elementary schools (boys) of District Mirpur there were 43 Govt. Elementary Schools for boys in District Mirpur. In order to meet time and financial constraint there 126 teachers teaching to class (6th to 8 th) were selected as a sample. A questionnaire was used to collect data from 126 teachers teaching in class 6th to class 8th.

\section{Findings}

i. Data collected were analyzed and findings were given in the tabulated form. The research findings, conclusion and recommendations are given as with respect to aspects of classroom management and their effect on management process:

ii. It indicated that static aspects include (classroom size, furniture, environment, students, teacher and availability of A, V- aids) a weighted mean value 4.1 that reflects that it has more impact on classroom management process as it has low value of standard deviation 0.55. It expressed the importance use of these inanities for effectiveness of teaching learning process and for well managed class room.

iii. The dynamic part of aspects includes (Students' behavior \& attitude, teacher behavior and attitude, atmosphere of the classroom, teaching methods and personality traits of the teacher.) indicated that weighted mean 3.1 which is low as compare to the highest value 5 . Therefore the reflection of this value indicated that human relationship between teacher and student and their behavior, attitude is not ideal with respect to classroom management.

iv. The data analysis about third part of the aspect of classroom management reveals that teachers' perception with respect to No of Students/Teachers, No of Teachers/class, Physical Resources, Availability of A.V aids and use of appropriate teaching methods have menace impact on ideal classroom environment. This part of data analysis shows that 3.7 value of mean is a critical one and also the value of standard deviation reflect the heterogeneous responses from the respondents, which show great variation from the opinion of teachers.

v. It made obvious that teachers are well qualified with professional education, but in spite of this teachers needs to update according to changes in curriculum and innovation in the field of education.

vi. It expressed the importance use of teaching methods/techniques for effectiveness of teaching learning process and for well managed class room. It made obvious that teachers are well qualified 
with professional education, but in spite of this teachers needs to update according to changes in curriculum and innovation in the field of education.

vii. Recommendations:

viii. Following recommendations were made that use of static elements may be made more flexible and appropriate. The attitude of teachers and physical restraints for management of classroom may not be favored, it discourage the learning process and have negative impact on the student attitude which cause of misbehavior and poor discipline of classroom. The attitude of teachers and students may be improved by the activity group discussion strategy. Teacher may be give resources and training to use the confidence developing techniques for proper grooming as well as for classroom management. It is also recommended that the class size may be reduced by making different section of class so that teacher can give proper time to all students in classroom.

\section{Refrences}

Adprima, (2005). Managing Student Conduct, Adprima towards the best, retrieved September 20, 2012 from http: \\www.proteacher.com/Managing Student Conduct.html.

Anderson, T (2000. Spring). Classroom Management Paper, Edpsy 3990L Retrieved October 02, 2012 from http://ww.irs.ed.ulue.edu/students/hale1/classmgm. html

Boice, M. (2003). Classroom Management Plan, Retrieved October, 2012 from Micaela Boice's Web Site at http://www.boicewebpage/teacher_studentportfoliows. htm

Education world (2003). Conflict Resolution Education: Four Aproaches; curriculum article. Retrieved November 20, 2012 from Education world; the educator's best friend at http://www.educationworld.com

Hale. M. \& Anderson, T. (Spring, 2000). Classroom Management Paper; EdPsy 399OL,

Retrieved December 12, 2012 from http://www.edpsy.Classroommanagement/hale/paper.htm

Hawley, C. (1997). Teacher talk: Tips for Creating a peaceful Classroom. Indiana University Center for Adoleseent Studies. Retrieved December 05, 2012 from http://www.indiana.edu/cafs.html

Kelly, M. (2005). Secondary School Educators; classroom Rules for Teachers Retrieved December 12, 2012 fromhttp://712educatorsabout.com/cs/backtoschool/a/classrules.htm.

Labell, K. (2005). Management and Organization, Retrieved December, 2012 from Kathelenelabell's portfolio at http://www.klabelle74.com

Lieberman, A. \&Miller.L. (1999). School Improvement: Themes and Variations. Teachers College, Columbia University, South Bend Schools, Indiana, Volume 86, Number 1, Fall 1999. Retrieved November 2012 from http://www.nap.edu/catalog/5592.html.

Mayeski, (2005). The Metamorphosis of Classroom Management: MOREL mid-continent research for education and learning, Retrieved November 08, 2012 from http://merel.org/claddroommanagement.html

Mynster, D. (1997). Classroom Management, Retrieved November 19, 2012 from http://geocities.com/athens /Delphi/4127/comm.html

Rayan (2005). Classroom management, Retrieved November 17, 2012 from http://www.mrryanclass.com/clasmanagement.hmtl

Solis, A. (2005). Classroom Management Plan. Retrieved November 21, 2012 from http://www.calstatela.edu/faculty/classmgmt.html 